\title{
Nutritional and Epidemiological Requirements for Growth and Sclerotia Formation by Sclerotium rolfsii (Sacc.) Causing Collar Rot of Chickpea (Cicer areitinum $\mathbf{L}$.)
}

\author{
Karan Singh*, C. B. Meena, Chirag Gautam, B. K. Patidar and N. R. Koli \\ Department of Plant Pathology, College of Agriculture, Ummedanj (Kota), India \\ *Corresponding author
}

\section{A B S T R A C T}

Keywords

Chickpea,

Sclerotium rolfsii,

Culture media, $\mathrm{pH}$,

Temperature,

Colony Growth and

Sclerotia formation

Article Info

Accepted:

08 June 2020

Available Online:

10 July 2020
Sclerotium rolfsii was isolated from infected chickpea plant sample collected from the chickpea's field of Agriculture Research Station, Ummedganj, (Kota). In epidemiological studies, mycelium growth and sclerotia formation by $S$. rolfsii was significantly influenced with media, temperature and $\mathrm{pH}$ level. Maximum colony diameter $(90.00 \mathrm{~mm})$ and sclerotia count (691.00 per plate) were recorded on oat meal agar (Hi-media) at $96 \mathrm{hrs}$. and 20 days after inoculation respectively, followed by potato dextrose agar (natural) in radial mycelial growth $87.00 \mathrm{~mm}$ and potato dextrose agar (Hi-Media) in number of sclerotia count 665.00 per plate. Maximum colony diameter $(90.00 \mathrm{~mm})$ and sclerotia counts $(538.50)$ of the pathogen were recorded at the $25{ }^{\circ} \mathrm{C}$ temperature was statistically superior over rest temperature level tried. While, in context to $\mathrm{pH}$ maximum colony diameter $89.00 \mathrm{~mm}$ of pathogen and sclerotia count 570.00 sclerotia per plate were recorded at the $\mathrm{pH}$ level 7.0.

\section{Introduction}

Chickpea is known in this country since ancient times. It is a widely grown major pulse crop in India, accounts for nearly 75 per cent of the total pulse production in the world. Chickpea crop is prone to many diseases viz., Fusarium wilt, dry root rot, collar rot, Ascochyta blight, Verticillium wilt, black root rot, Phytophthora root rot, wet root rot, foot rot, Pythium rot and seed rot etc. Among these, collar rot caused by Sclerotium rolfsii which is gaining importance. Collar rot of chickpea is well known and wide spread disease in India. About 2-5\% of losses are caused every year which may even reach up to $60 \%$ under severe conditions.

It was reported that 54.7 - 95\% of mortality occurred in chickpea seedlings because of collar rot disease (Mathur and Sinha, 1968). Sclerotium rolfsii is an economically important pathogen on numerous crops worldwide. 
It has an extensive host range; at least 500 species in 100 families are susceptible, the most common hosts are legumes, crucifers and cucurbits, and commonly occurs in the tropics, subtropics, and other warm temperate regions (Punja, 1985). Present experiment deals with study of Sclerotium rolfsii growth and sclerotia formation under different culture media, at various temperatures and $\mathrm{pH}$ level. To carry out the research, eight distinctive culture media viz.,Potato dextrose agar (Natural), Potato dextrose agar (Hi-Media), V-8 juice agar (Hi-Media), C-zepak'sagar (Hi-Media), Oat meal agar (Hi-Media), Corn meal agar, Chickpea seed meal extract agar and Host (Chickpea) stem extract agar were used to evaluate the growth and sclerotia formation of pathogen. Later suitable temperature and $\mathrm{pH}$ were also analyzed for the pathogen growth and sclerotia formation by incubating at different $\mathrm{pH}$ level viz., 5.0, 6.0, 7.0, 8.0 and 8.5 and temperatures level viz., $10^{\circ} \mathrm{C}, 15^{\circ} \mathrm{C}, 20^{\circ} \mathrm{C}, 25^{\circ} \mathrm{C}, 30^{\circ} \mathrm{C}$ and $35^{\circ} \mathrm{C}$.

\section{Materials and Methods}

\section{Collection}

Infected plants which showing typical collar rot symptoms were collected during month of October to December, 2018 from the chickpea fields of Agriculture Research Station, Ummedganj (Kota). Samples were brought in to Department of Plant Pathology, College of Agriculture, Ummedganj, (Kota) for isolation and further studies.

\section{Isolation of fungus}

For isolation of the pathogen standard tissue isolation technique followed. The part of collar region showing typical symptoms of disease was cut into small pieces $\left(3 \mathrm{~mm}^{2}\right)$. Then these pieces were surface sterilized with $0.1 \% \mathrm{HgCl}_{2}$ solution for one minute. Such pieces were washed thoroughly in sterile distilled water three times to remove the traces of mercuric chloride solution, and then aseptically transferred to sterilized potato dextrose agar (PDA) plates. They were incubated at $25 \pm 1^{\circ} \mathrm{Cfor}$ three days for growth of fungus. Later, the bit of fungal growth was transferred to PDA plates. The pure culture of fungus was obtained by further growing the culture and following hyphal tip culture under aseptic conditions.

\section{Identification of fungus}

The pathogen S. rolfsii forms cottony white colonies on PDA. The colonies appeared as dull white to pure white mycelial growth and formed sclerotial bodies after 8-9 days of incubation. Sclerotia are brown in colour and mustard seed like in shape. On the basis of these characters pathogen was identified as $S$. rolfsii. Further, pathogen was identified from ITCC (Indian Type Culture Collection) Lab, IARI, Division of Plant Pathology, New Delhi (Ref. No. PP/3260; date- 25/03/2019).

\section{Preparation of culture media}

Different culture media viz.,Potato dextrose agar (Natural), Potato dextrose agar (HiMedia), V-8 juice agar (Hi-Media), C-zepak's agar (Hi-Media), Oat meal agar (Hi-Media), Corn meal agar, Chickpea seed meal extract agar and Host (Chickpea) stem extract agar were prepared to carry out the study. All the media were sterilized at $121.6{ }^{\circ} \mathrm{C}$ temperature and $1.05 \mathrm{~kg} / \mathrm{cm}^{2}$ (15lbs psi) pressure for 15 min. To carry out study, cool \& molten media near about $20 \mathrm{ml}$ of each of the medium was poured in each prior Sterilized petriplates. After solidification of media such petriplates were inoculated with $6 \mathrm{~mm}$ disc cut from the periphery of actively growing fungal culture grown in petri plates by using sterilized cork borerand incubated at $25 \pm 1{ }^{\circ} \mathrm{C}$. Each treatment was replicated thrice. Radial growth 
of the colony was recorded by measuring the colony diameter in millimetre at regular intervals of $48 \mathrm{hrs}$ and sclerotia count at $20^{\text {th }}$ day. The data obtained were analysed statistically.

\section{Effect of variable temperatures on growth and sclerotia formation of $S$. rolfsii, in-vitro}

To determine the minimum, optimum and maximum range of temperature for mycelial growth and sclerotia formation of Sclerotium rolfsii, PDA was poured into the petriplates and a $6 \mathrm{~mm}$ mycelial disc from actively growing culture of the fungus placed on the surface of solidified medium $(20 \mathrm{ml}$ for each Petri plate) in a laminar air flow. The inoculated plates were incubated at different regimes of temperature viz., 10, 15, 20, 2530 and $35 \pm 1{ }^{\circ} \mathrm{C}$ in different BOD incubator. Four replications were maintained for each temperature level. Radial growth of the colony was recorded by measuring colony diameter in millimetre at regular intervals of $48 \mathrm{hrs}$. and sclerotia count at $20^{\text {th }}$ day. The data obtained were analysed statistically.

Effect of variable pH on growth and sclerotia formation of $S$. rolfsii, in-vitro

For determining the optimum level of $\mathrm{pH}$ for mycelial growth and sclerotia formation of Sclerotium rolfsii, $100 \mathrm{ml}$ of medium (PDA) was dispensed into the 5 Erlenmeyer flasks of $250 \mathrm{ml}$ capacity and different regimes of $\mathrm{pH}$ viz., 5.0, 6.0, 7.0, 8.0 and 8.5 were adjust by with the Digital $\mathrm{pH}$ meter by using $\mathrm{N} / 10 \mathrm{HCl}$ or N/10 NaOH solution prior to sterilization. The sterilized medium was poured into petriplates. After solidification of medium, a 6 $\mathrm{mm}$ mycelial disc from actively growing culture of fungus was cut with sterilized cork borer and placed on the surface of medium (20 $\mathrm{ml}$ for each Petri plate) under aseptic condition. The inoculated plates were incubated at $25 \pm 1^{\circ} \mathrm{C}$. Four replications were maintained for each treatment of $\mathrm{pH}$ level. Radial growth of the colony was recorded by measuring colony diameter in millimetre at regular intervals of $48 \mathrm{hrs}$ and sclerotia count at $20^{\text {th }}$ day. The data obtained were analysed statistically.

\section{Results and Discussion}

Effect of different solid culture media on mycelial growth and sclerotia formation of S. rolfsii

Effect of different solid media, viz., Potato dextrose agar (Natural), Potato dextrose agar (Hi-Media), V-8 juice agar (Hi-Media), Czepak'sagar (Hi-Media), Oat meal agar (HiMedia), Corn meal agar, Chickpea seed meal extract agar and Host (Chickpea) stem extract agar on radial growth and sclerotia formation was studied and observation have been presented in Table- 1, illustrated in Fig.-1(a) or (b)and Plate-1(a) \& (b). Maximum colony diameter $(90.00 \mathrm{~mm})$ and sclerotia count (691.00) were recorded on oat meal agar (Himedia) at $96 \mathrm{hrs}$. and 20 days after inoculation respectively, which was statistically significant over rest of medium tried, Similar result were also reported by (Basamma2008; Sab, 2013). The next was potato dextrose agar (Natural) medium which yielded $87.00 \mathrm{~mm}$, colony diameter followed by C-zapek's agar medium and chickpea seed meal extract agar both were similar and yielded $84.25 \mathrm{~mm}$ growth of fungus, potato dextrose agar (HiMedia) yielded $83.25 \mathrm{~mm}$ radial growth which were also statistically at par each other. Least colony diameter $(56.63 \mathrm{~mm})$ of the pathogen was observed in host stem (chickpea) extract agar medium and it was statistically inferior than all other agar medium tried. In number of sclerotia count per platesoat meal agar (Hi-media) was followed by potato dextrose agar (Hi-Media), potato dextrose agar (natural), C-Zepak'sagar (Hi-Media) and V-8 juice agar (Hi-Media) in 
numbers respectively $665.00,628.00,390.00$ and 334.00. Very minute sizes sclerotia is appeared in V-8 juice agar (Hi-Media). Least sclerotia produced in chickpea seed meal extract agar 137.00 was statistically inferior than all other agar medium used, similar finding regarding potato dextrose agar (PDA) medium was found to be highly supportive for the pathogen growth resulting full growth $(9 \mathrm{~cm})$ within 7 days (Bana Sravani and Ram Chandra, 2020).

\section{Effect of different temperature level on radial growth and sclerotia formation of $S$. rolfsii}

The temperature ranges for growth vary for all microorganisms as well as for host pathogen interactions. The fungus showed considerable variation in mycelial growth and sclerotia formation at different temperature level studies on PDA viz., 10, 15, 20, 25, 30 and $35^{\circ} \mathrm{C}$. It's evident from data presented in Table- 2, illustrated in Fig.- 2(a) or (b) and Plate- 2(a) \& (b) that $S$. rolfsii grew at temperature ranges 10 to $35^{\circ} \mathrm{C}$ under study.The fungus had showing considerable variation in radial growth and sclerotia formation at different temperature level studies viz., 10, 15, 20, 25, 30 and $35^{\circ} \mathrm{C}$, maximum colony diameter $(90.00 \mathrm{~mm})$ of the pathogen was recorded at the $25^{\circ} \mathrm{C}$ temperature was statistically superior over rest temperature level tried and found ideal for the growth of pathogen followed by $30^{\circ} \mathrm{C}(85.00 \mathrm{~mm})$ and least growth observed at $10^{\circ} \mathrm{C}(22.63 \mathrm{~mm})$. Results indicate that both increase and decrease in level of the temperature significantly alter mycelial growth and growth rate of pathogen. In context to number of sclerotia formation per plates was maximum at $25^{\circ} \mathrm{C}$ temperature with sclerotia count (538.50), followed by $30^{\circ} \mathrm{C}$ (480.50). The less numbers of sclerotia wereproduced at $10^{\circ} \mathrm{C} \quad(185.25)$ was statistically inferior than all other temperature level tested. Similar finding regarding mycelial growth and number of sclerotia formation was reported by Dey et al., (1992) found that most sclerotia were obtained in culture medium on P.D.A., the mycelial and sclerotia formation was best over the temperatures range of $25-30^{\circ} \mathrm{C}$. Prasad et al., (1986) reported that best mycelial growth of S. rolfsii at $30 \pm 0.5^{\circ} \mathrm{C}$, whereas $25 \pm 0.5^{\circ} \mathrm{C}$ for the sclerotial formation.Zape et al., (2013) observed that the Sclerotium rolfsii showed rapid mycelia growth at $30^{\circ} \mathrm{C}$ and maximum sclerotial production was recorded at $25^{\circ} \mathrm{C}$ the pathogen was unable to grow and produce sclerotia at minimum \& maximum temperatures of $10^{\circ} \mathrm{C}$ and $40^{\circ} \mathrm{C}$ studied. Muthukumar and Suthinraj (2019) revealed that the maximum mycelia growth and biomass produced by pathogen at $30^{\circ} \mathrm{C}$ $(89.33 \mathrm{~mm} ; 240 \mathrm{mg})$ which was significantly reduced below $20^{\circ} \mathrm{C}$ and above $35^{\circ} \mathrm{C}$. Bana Sravani and Ram Chandra (2020) found that $30^{\circ} \mathrm{C}$ with maximum mycelial growth of 9.0 $\mathrm{cm}$ within 5 DAI followed by $25^{\circ} \mathrm{C}$ temperature with $9.0 \mathrm{~cm}$ at 7 DAI whereas other temperature ranges gradually reduced the growth of pathogen. Least growth was noticed when pathogen was allowed to grow at $15^{\circ} \mathrm{C}$ and $35^{\circ} \mathrm{C}$ with only 5.60 and $5.13 \mathrm{~cm}$ radial growth at 7 DAI.

\section{Effect of different $\mathrm{pH}$ level on mycelial growth and sclerotia formation of $S$. rolfsii}

The $\mathrm{pH}$ value of a medium has a marked effect on radial growth and sclerotia formation by $S$. rolfsii. The fungus had showing considerable variation in radial growth and sclerotia formation at different $\mathrm{pH}$ level viz., 5.0, 6.0, 7.0, 8.0 and 8.5 was studied and observation have been presented in Table- 3, illustrated in Fig.- 3(a) or (b) and Plate- 3(a) \& (b). The $\mathrm{pH}$ value of medium has a noticeable effect on radial growth and sclerotia formation by $S$. rolfsii. 
The fungus had showing substantial variation in radial growth and sclerotia formation at different $\mathrm{pH}$ level viz., 5.0, 6.0, 7.0, 8.0 and 8.5 was studied, maximum colony diameter $89.00 \mathrm{~mm}$ of pathogen was recorded at the $\mathrm{pH}$ level 7.0,This was followed by $\mathrm{pH}$ level 6.0, 5.0, 8.0 and 8.5 with colony diameter 82.75 , $70.75,62.75 \mathrm{~mm}$ and $56.75 \mathrm{~mm}$ of the $S$. rolfsii respectively. Result indicates that both increase and decrease in the level of $\mathrm{pH}$ significantly alter mycelial growth of Pathogen. Maximum number of sclerotia 570.00 recorded at $\mathrm{pH}$ level 7.0 per plate which was statistically at par $\mathrm{pH}$ level 8.0 with numbers of sclerotia 538.00per plates.
Least sclerotia produced in medium having pH 5.0 (232.00) was statistically inferior than all other $\mathrm{pH}$ level tested. This shows that pathogen requires slightly acidic condition for its growth and sclerotial formation.

Similar finding reported by Kumar et al., (2008) also reported that maximum growth obtained at $\mathrm{pH} 6.5$ followed by $\mathrm{pH}$ 7.0. Zape et al., (2013) reported maximum radial growth of $S$. rolfsii observed at $\mathrm{pH} 6.5$ followed by $\mathrm{pH} 6.0$ and 7.0 and whereas, maximum sclerotial formation at $\mathrm{pH} 7.0$. optimum range of $\mathrm{pH} 5.5$ to 7.5 was better for pathogen growth and sclerotial formation.

Table.1 Effect of different solid culture medium on mycelial growth and sclerotia formation by Sclerotium rolfsii, in-vitro

\begin{tabular}{|c|c|c|c|c|}
\hline S. No. & Medium Name & $\begin{array}{l}\text { Average colony } \\
\text { diameter (48 } \\
\text { hrs. after in } \\
\text { mm)* }\end{array}$ & $\begin{array}{l}\text { Average colony } \\
\text { diameter (96 } \\
\text { hrs. after in } \\
\text { mm) } *\end{array}$ & $\begin{array}{c}\text { Average } \\
\text { Number of } \\
\text { Sclerotia } \\
(20 D A I) *\end{array}$ \\
\hline 1. & Potato dextrose agar (Natural) & $\begin{array}{c}64.75 \\
(53.58) * *\end{array}$ & $\begin{array}{c}87.00 \\
(68.89)\end{array}$ & $\begin{array}{c}628.00 \\
(25.07) * * *\end{array}$ \\
\hline 2. & Potato dextrose agar (Hi-Media) & $\begin{array}{c}61.50 \\
(51.65)\end{array}$ & $\begin{array}{c}83.25 \\
(65.85)\end{array}$ & $\begin{array}{l}665.00 \\
(25.80)\end{array}$ \\
\hline 3. & V-8 juice Agar (Hi-Media) & $\begin{array}{c}39.50 \\
(38.94)\end{array}$ & $\begin{array}{c}57.75 \\
(49.46)\end{array}$ & $\begin{array}{l}334.00 \\
(18.29)\end{array}$ \\
\hline 4. & C-zepak’s Agar (Hi-Media) & $\begin{array}{c}63.50 \\
(52.83)\end{array}$ & $\begin{array}{c}84.25 \\
(66.63)\end{array}$ & $\begin{array}{l}390.00 \\
(19.74)\end{array}$ \\
\hline 5. & Oat meal Agar (Hi-Media) & $\begin{array}{c}66.75 \\
(54.79)\end{array}$ & $\begin{array}{l}90.00 \\
(71.57)\end{array}$ & $\begin{array}{l}691.00 \\
(26.30)\end{array}$ \\
\hline 6. & Corn meal Agar & $\begin{array}{c}46.75 \\
(43.14)\end{array}$ & $\begin{array}{c}74.00 \\
(59.35)\end{array}$ & $\begin{array}{l}190.00 \\
(13.80)\end{array}$ \\
\hline 7. & Chickpea seed meal extract Agar & $\begin{array}{c}54.75 \\
(47.73)\end{array}$ & $\begin{array}{c}84.25 \\
(66.62)\end{array}$ & $\begin{array}{l}137.00 \\
(11.72)\end{array}$ \\
\hline 8. & Chickpea stem extract Agar & $\begin{array}{c}36.50 \\
(37.17)\end{array}$ & $\begin{array}{c}54.63 \\
(47.65)\end{array}$ & $\begin{array}{l}273.00 \\
(16.54)\end{array}$ \\
\hline \multicolumn{2}{|c|}{$\begin{array}{l}\text { SEm. } \pm= \\
\text { C.D. at } 0.05 \%= \\
\text { C.V. }(\%)=\end{array}$} & $\begin{array}{l}0.77(0.45) \\
1.59(0.94) \\
2.01(1.35)\end{array}$ & $\begin{array}{l}0.81(0.58) \\
1.66(1.20) \\
1.48(1.33)\end{array}$ & $\begin{array}{c}14.14(0.35) \\
29.19(0.73) \\
4.84(2.55)\end{array}$ \\
\hline
\end{tabular}

*Mean of four replications; **Figures in parentheses are Arc sine transformed values;

***Figures in parentheses are Square root transformed values 
Table.2 Effect of different temperature level on mycelial growth and sclerotia formation by Sclerotium rolfsii, in-vitro

\begin{tabular}{|c|c|c|c|c|c|}
\hline $\begin{array}{l}\text { S. } \\
\text { No. }\end{array}$ & $\begin{array}{l}\text { Temperature } \\
\left({ }^{\circ} \mathrm{C}\right)\end{array}$ & $\begin{array}{l}\text { Average colony } \\
\text { diameter ( } 48 \\
\text { hrs. after in } \\
\text { mm) } *\end{array}$ & $\begin{array}{l}\text { Average colony } \\
\text { diameter ( } 96 \\
\text { hrs. after in } \\
\text { mm) } *\end{array}$ & $\begin{array}{l}\text { Time taken in } \\
\text { hrs. for cover } \\
\text { whole plates by } \\
\text { fungal growth }\end{array}$ & $\begin{array}{l}\text { Average } \\
\text { Number of } \\
\text { Sclerotia } \\
(\text { 20DAI) } *\end{array}$ \\
\hline 1. & $10^{\circ} \mathrm{C}$ & $\begin{array}{c}11.00 \\
(19.35) * *\end{array}$ & $\begin{array}{c}22.63 \\
(28.39)\end{array}$ & 182 & $\begin{array}{c}185.25 \\
(13.63) * * *\end{array}$ \\
\hline 2. & $15^{\circ} \mathrm{C}$ & $\begin{array}{c}20.88 \\
(27.18)\end{array}$ & $\begin{array}{c}32.88 \\
(34.98)\end{array}$ & 168 & $\begin{array}{l}204.00 \\
(14.29)\end{array}$ \\
\hline 3. & $20^{\circ} \mathrm{C}$ & $\begin{array}{c}41.50 \\
(40.11)\end{array}$ & $\begin{array}{c}67.63 \\
(55.32)\end{array}$ & 130 & $\begin{array}{l}360.00 \\
(18.98)\end{array}$ \\
\hline 4. & $25^{\circ} \mathrm{C}$ & $\begin{array}{c}62.88 \\
(52.46)\end{array}$ & $\begin{array}{c}90.00 \\
(71.57)\end{array}$ & 96 & $\begin{array}{l}538.50 \\
(23.21)\end{array}$ \\
\hline 5. & $30^{\circ} \mathrm{C}$ & $\begin{array}{c}59.75 \\
(50.62)\end{array}$ & $\begin{array}{c}85.00 \\
(67.22)\end{array}$ & 120 & $\begin{array}{l}480.50 \\
(21.93)\end{array}$ \\
\hline 6. & $35^{\circ} \mathrm{C}$ & $\begin{array}{c}28.63 \\
(32.34)\end{array}$ & $\begin{array}{c}56.63 \\
(48.81)\end{array}$ & 144 & $\begin{array}{l}285.00 \\
(16.89)\end{array}$ \\
\hline \multicolumn{2}{|c|}{$\begin{array}{l}\text { SEm. } \pm= \\
\text { C.D. at } 0.05 \%= \\
\text { C.V. }(\%)=\end{array}$} & $\begin{array}{l}0.68(0.47) \\
1.44(0.99) \\
2.58(1.80)\end{array}$ & $\begin{array}{l}0.86(0.56) \\
1.81(1.18) \\
2.06(1.55)\end{array}$ & & $\begin{array}{c}13.37(0.34) \\
28.08(0.72) \\
5.52(2.67)\end{array}$ \\
\hline
\end{tabular}

Table.3 Effect of different $\mathrm{pH}$ level on mycelial growth and sclerotia formation by Sclerotium rolfsii, in-vitro

\begin{tabular}{|c|c|c|c|c|}
\hline S. No. & pH level & $\begin{array}{c}\text { Average colony } \\
\text { diameter }(48 \text { hrs. after } \\
\text { in } \mathrm{mm}) *\end{array}$ & $\begin{array}{c}\text { Average colony } \\
\text { diameter }(96 \mathrm{hrs} \text {. after } \\
\text { in } \mathrm{mm}) *\end{array}$ & $\begin{array}{l}\text { Average Number of } \\
\text { Sclerotia (20DAI) * }\end{array}$ \\
\hline 1. & 5.0 & $\begin{array}{c}44.00 \\
(41.55) * *\end{array}$ & $\begin{array}{c}70.75 \\
(57.26)\end{array}$ & $\begin{array}{c}232.00 \\
(15.22) * * *\end{array}$ \\
\hline 2. & 6.0 & $\begin{array}{c}50.00 \\
(45.00)\end{array}$ & $\begin{array}{c}82.75 \\
(65.47)\end{array}$ & $\begin{array}{l}388.00 \\
(19.71)\end{array}$ \\
\hline 3. & 7.0 & $\begin{array}{c}56.50 \\
(48.74)\end{array}$ & $\begin{array}{c}89.00 \\
(70.66)\end{array}$ & $\begin{array}{l}570.00 \\
(23.87)\end{array}$ \\
\hline 4. & 8.0 & $\begin{array}{c}35.75 \\
(36.72)\end{array}$ & $\begin{array}{c}62.75 \\
(52.39)\end{array}$ & $\begin{array}{l}538.00 \\
(23.20)\end{array}$ \\
\hline 5. & 8.5 & $\begin{array}{c}27.75 \\
(31.78)\end{array}$ & $\begin{array}{c}56.75 \\
(48.88)\end{array}$ & $\begin{array}{l}335.00 \\
(18.31)\end{array}$ \\
\hline \multicolumn{2}{|c|}{$\begin{array}{l}\text { SEm. } \pm= \\
\text { C.D. at } 0.05 \%= \\
\text { C.V. }(\%)=\end{array}$} & $\begin{array}{l}1.02(0.61) \\
2.18(1.30) \\
3.39(2.12)\end{array}$ & $\begin{array}{l}1.12(0.75) \\
2.38(1.60) \\
2.18(1.80)\end{array}$ & $\begin{array}{c}19.78(0.51) \\
42.17(1.08) \\
6.78(3.56)\end{array}$ \\
\hline
\end{tabular}

*Mean of four replications; **Figures in parentheses are Arc sine transformed values;

$* * *$ Figures in parentheses are Square root transformed values 


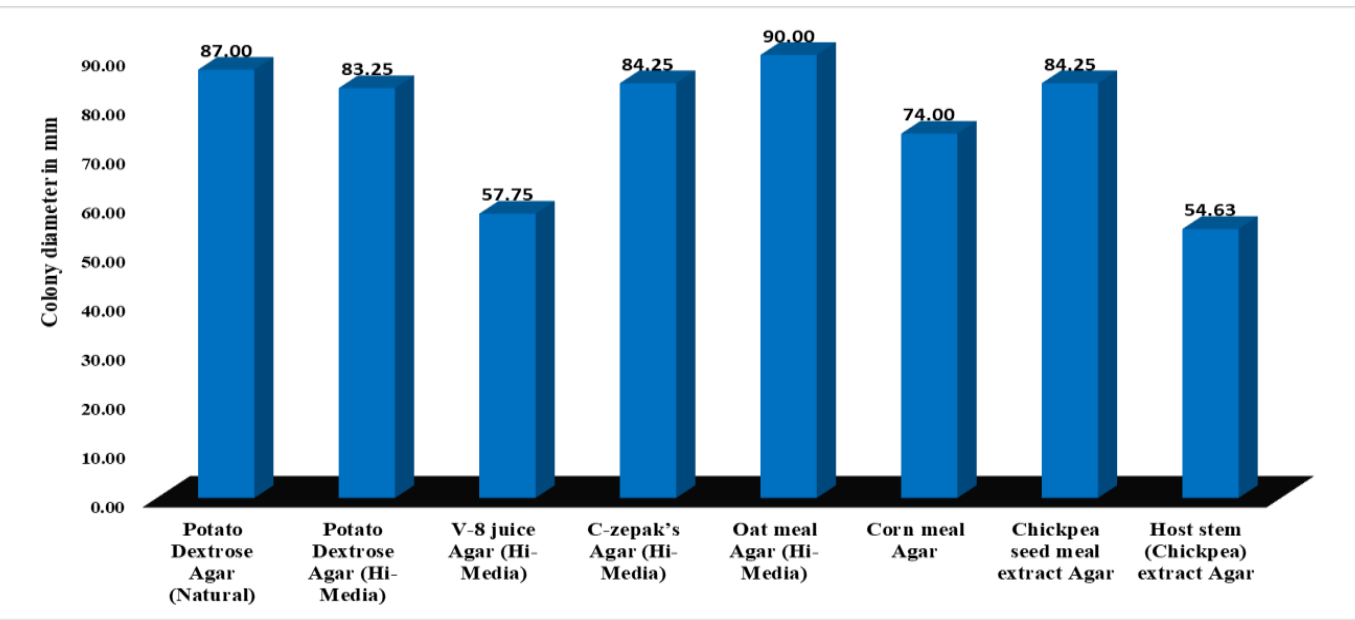

Fig.1(a) Effect of different solid media on mycelial growth of $S$. rolfsii (96 hrs. after inoculation)

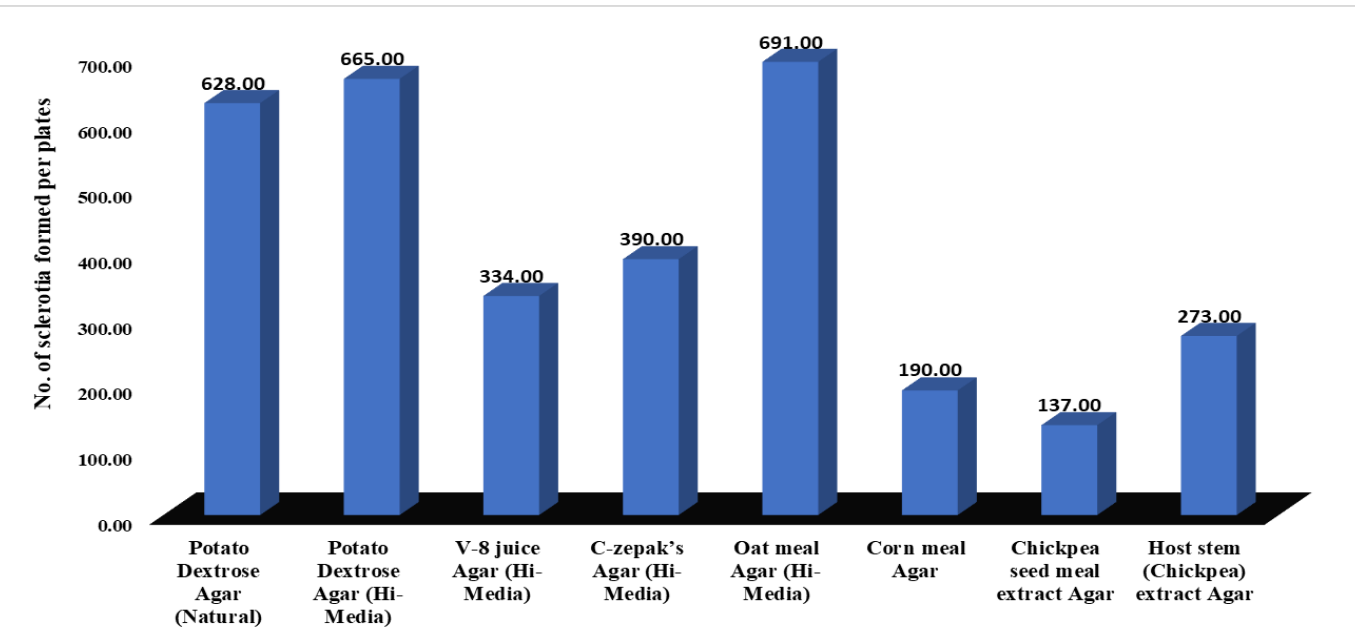

Fig.1(b) Effect of different solid media on sclerotia formation by S. rolfsii

(20 days after inoculation)

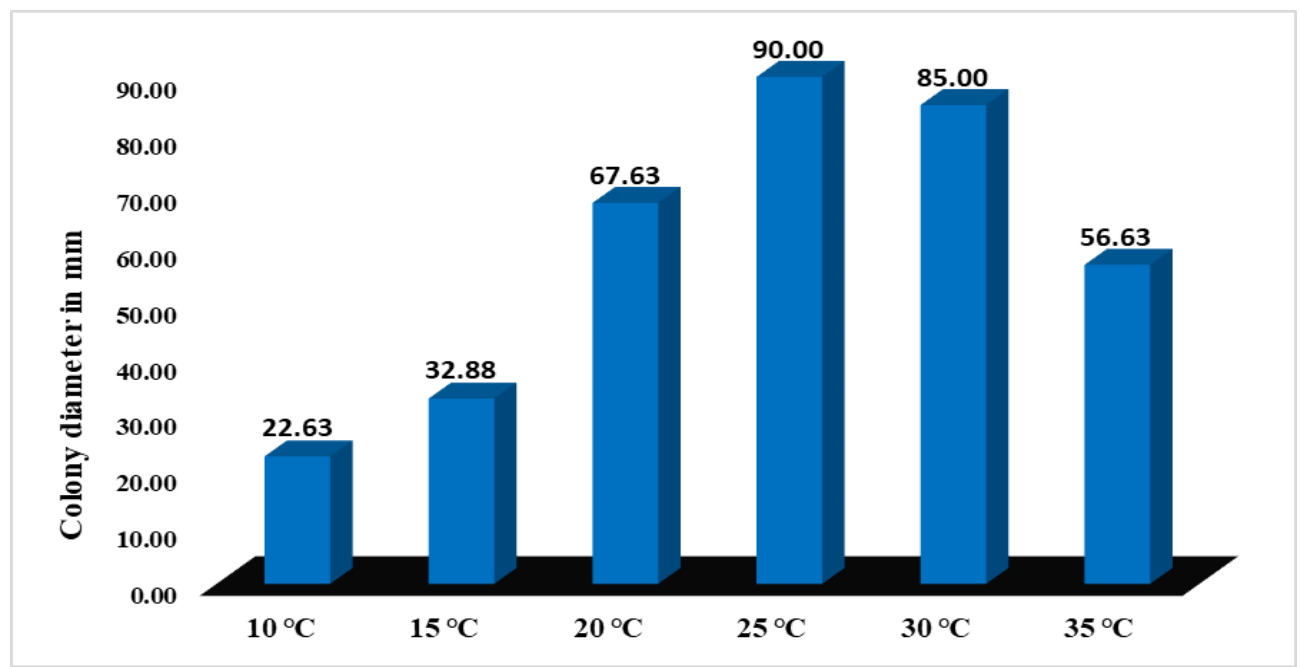

Fig.2(a) Effect of different temperature level on mycelial growth of $S$. rolfsii (96 hrs. after inoculation) 


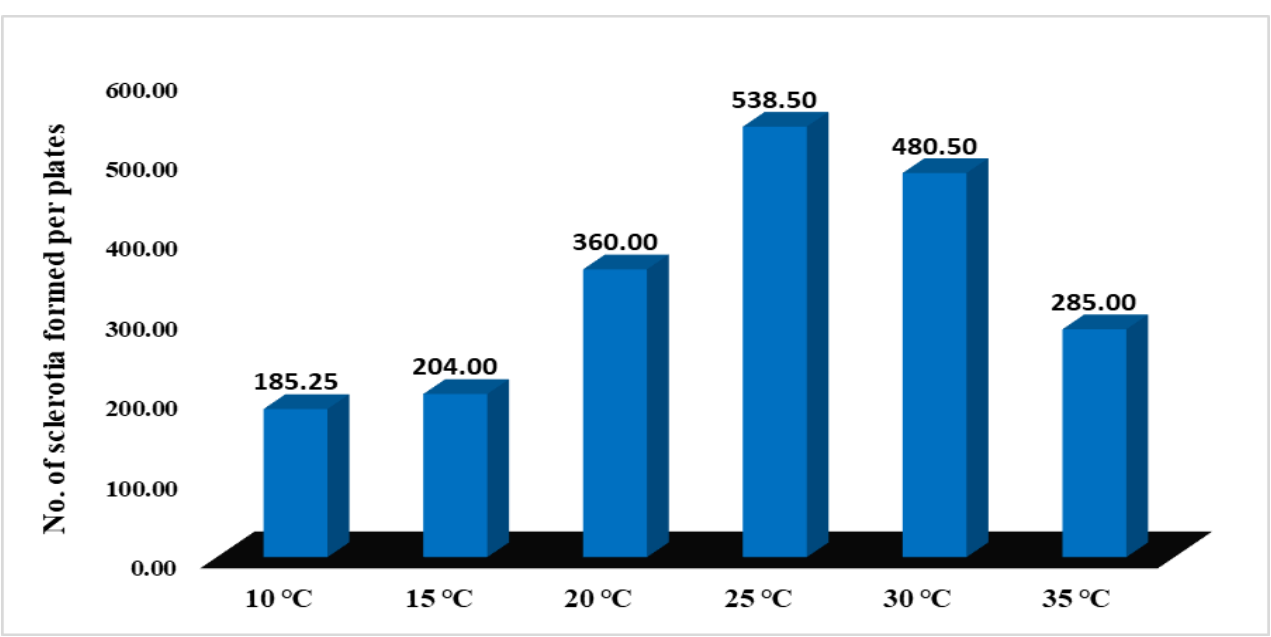

Fig.2(b) Effect of different temperature level on sclerotia formation by $S$. rolfsii (20 days after inoculation)

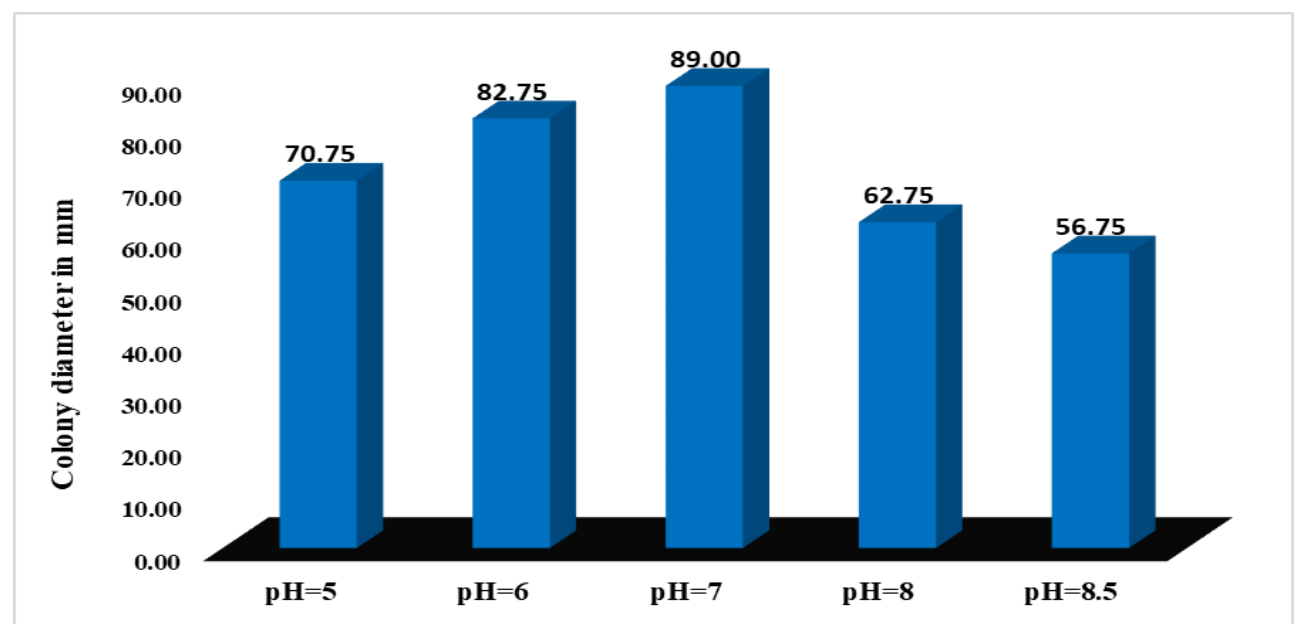

Fig.3(a) Effect of different $\mathrm{pH}$ level on mycelial growth of $S$. rolfsii (96 hrs. after inoculation)

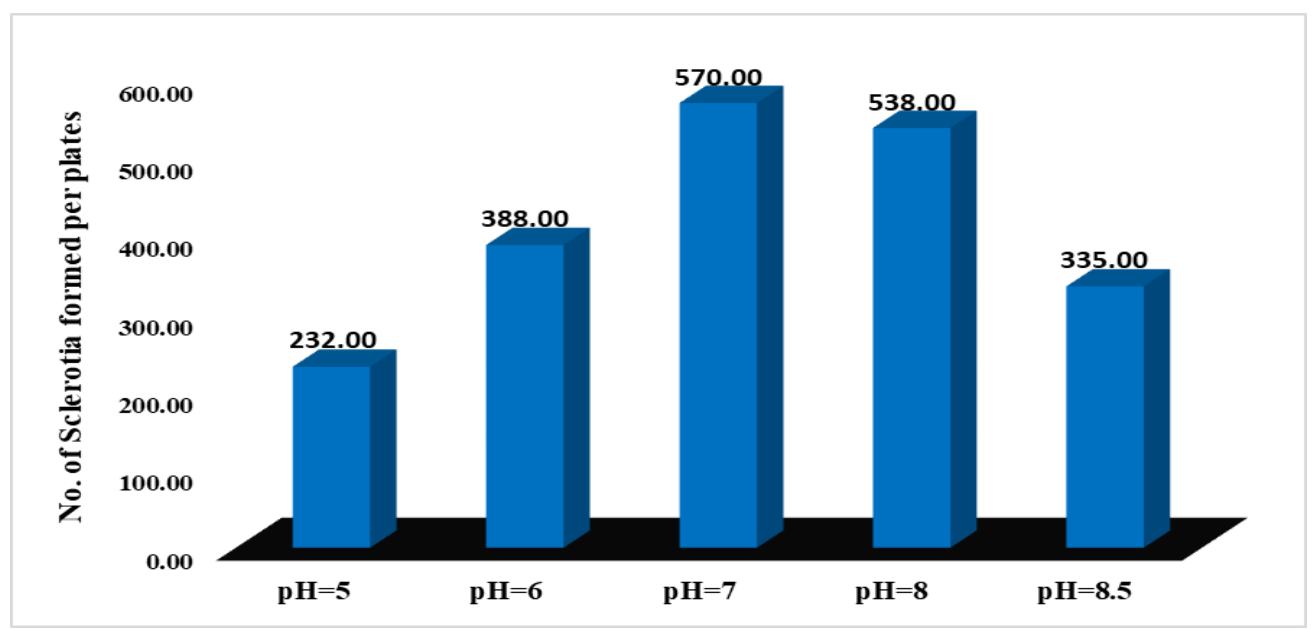

Fig.3(b) Effect of different $\mathrm{pH}$ level on sclerotia formation by $S$. rolfsii (20 days after inoculation) 


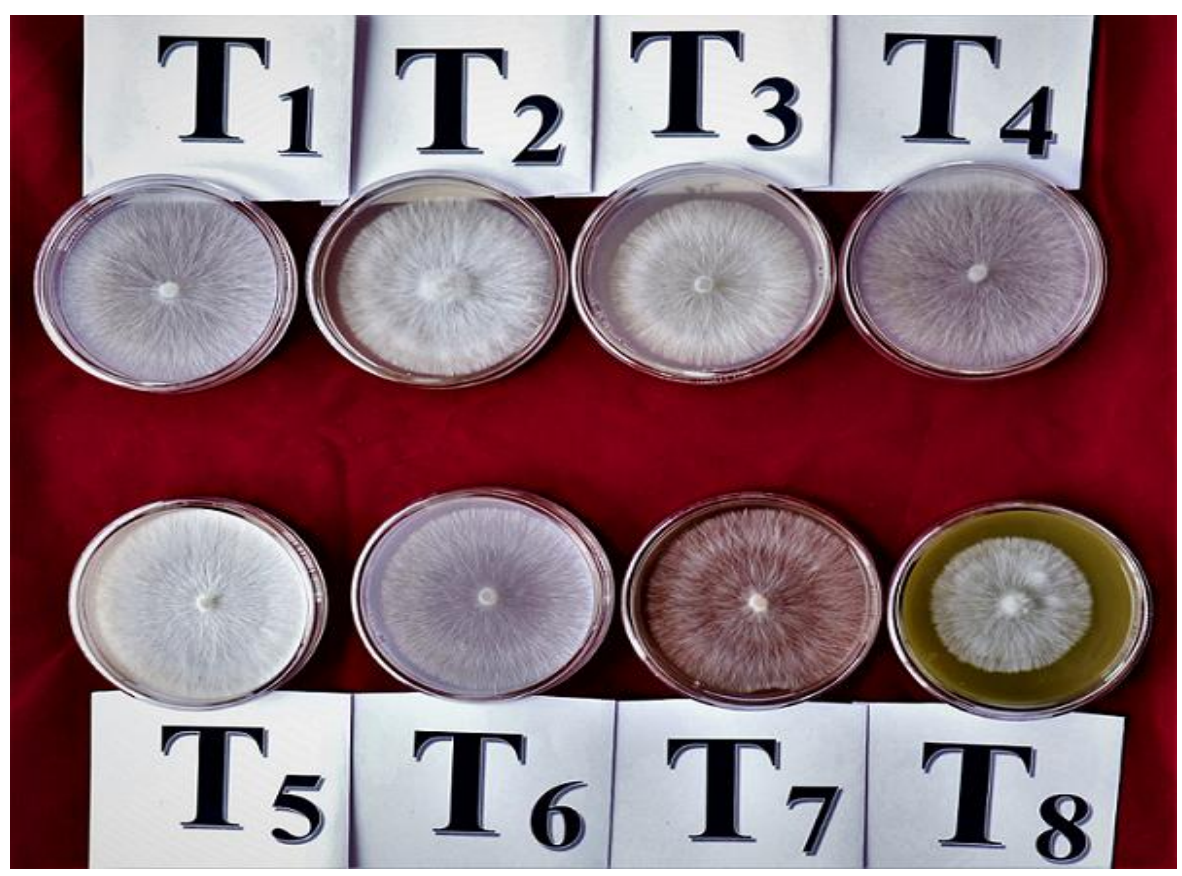

$\mathrm{T}_{1}=$ Potato dextrose agar (Natural), $\mathrm{T}_{2}=$ Potato dextrose agar $(\mathrm{Hi}-\mathrm{Media}), \mathrm{T}_{3}=\mathrm{V}-8$ juice agar $(\mathrm{Hi}$ Media), $\mathrm{T}_{4}=\mathrm{C}$-zepak's agar (Hi-Media), $\mathrm{T}_{5}=$ Oat meal agar $\left(\right.$ Hi-Media), $\mathrm{T}_{6}=$ Corn meal agar, $\mathrm{T}_{7}=$ Chickpea seed meal extract agar, $\mathrm{T}_{8}=$ Chickpea stem extract agar Plate.1(a) Effect of different solid media on mycelial growth of $S$. rolfsii (96 hrs. after inoculation)

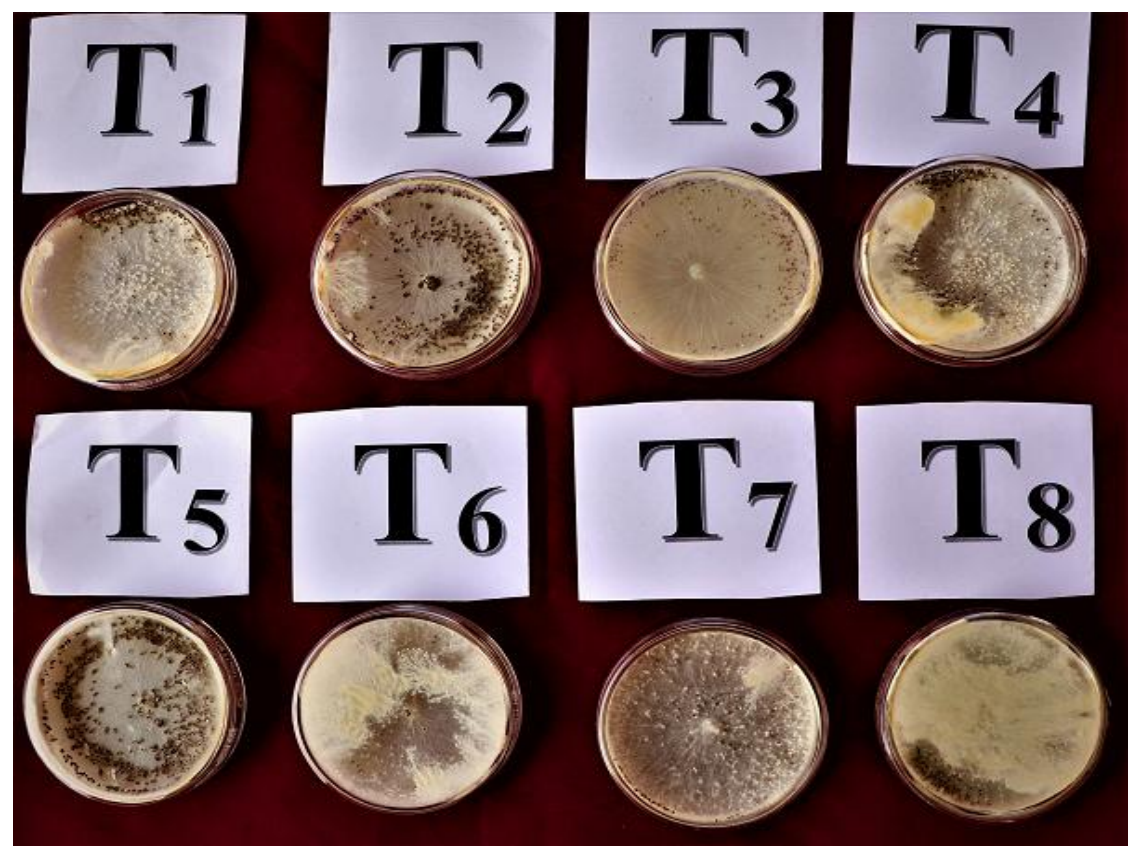

$\mathrm{T}_{1}=$ Potato dextrose agar (Natural), $\mathrm{T}_{2}=$ Potato dextrose agar $(\mathrm{Hi}-\mathrm{Media}), \mathrm{T}_{3}=\mathrm{V}-8$ juice agar $\left(\mathrm{Hi}^{-}\right.$

Media), $\mathrm{T}_{4}=\mathrm{C}$-zepak's agar (Hi-Media), $\mathrm{T}_{5}=$ Oat meal agar $(\mathrm{Hi}-\mathrm{Media}), \mathrm{T}_{6}=$ Corn meal agar, $\mathrm{T}_{7}=$ Chickpea seed meal extract agar, $\mathrm{T}_{8}=$ Chickpea stem extract agar Plate.1(b) Effect of different solid media on sclerotia formation by S. rolfsii (20 days after inoculation) 


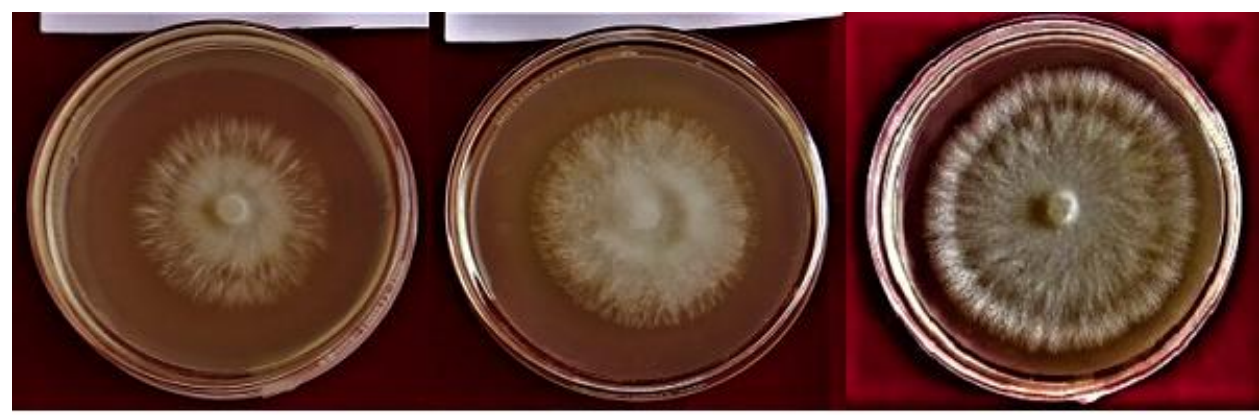

$10^{\circ} \mathrm{C}$

$15^{\circ} \mathrm{C}$

$20^{\circ} \mathrm{C}$

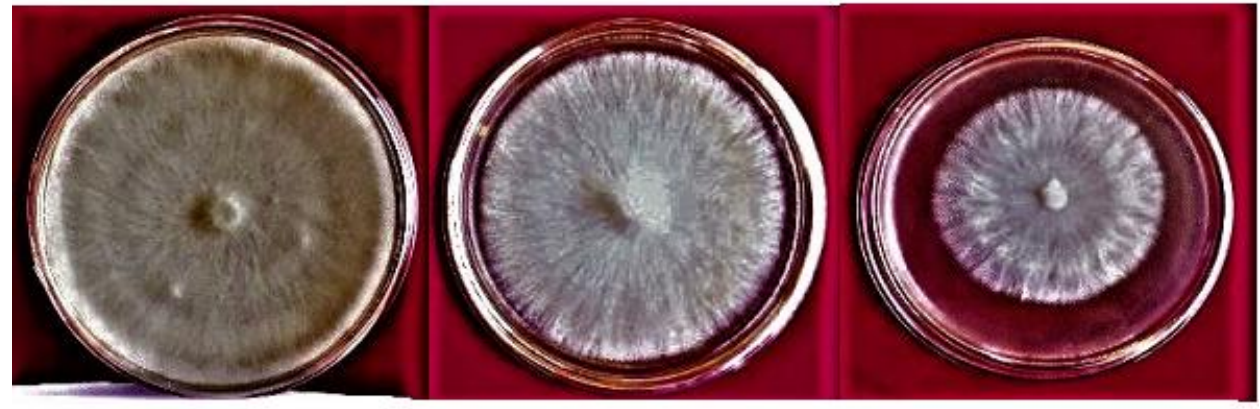

$25^{\circ} \mathrm{C}$

$30^{\circ} \mathrm{C}$

$35^{\circ} \mathrm{C}$

Plate.2(a) Effect of different temperature level on mycelial growth of S. rolfsii (96 hrs. after inoculation)

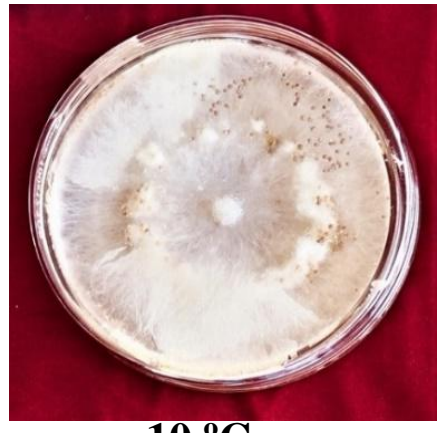

$10{ }^{\circ} \mathrm{C}$

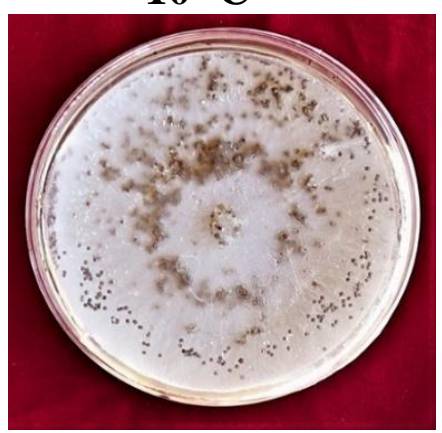

$25^{\circ} \mathrm{C}$

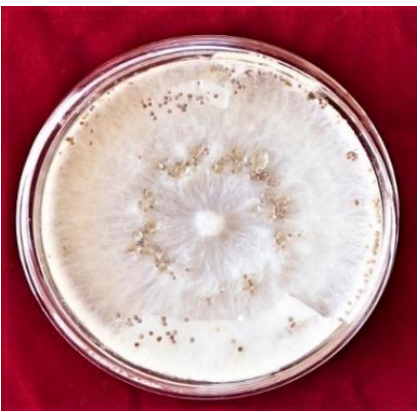

$15^{\circ} \mathrm{C}$

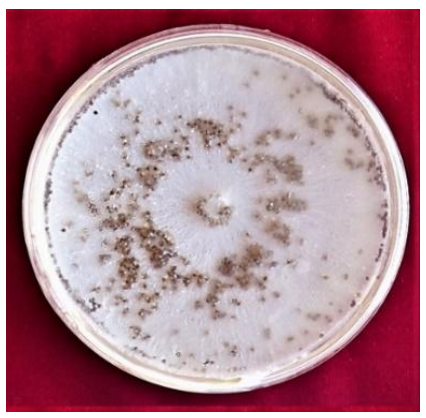

$30^{\circ} \mathrm{C}$

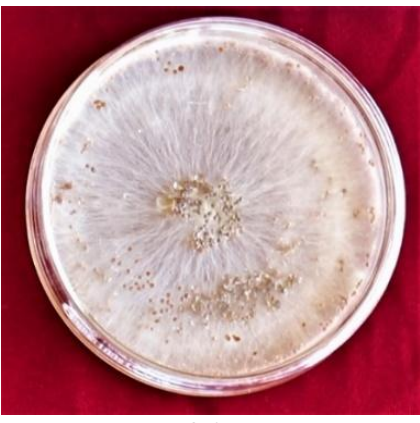

$20^{\circ} \mathrm{C}$

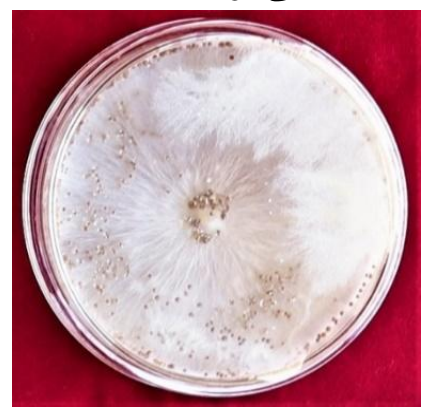

$35^{\circ} \mathrm{C}$

Plate.2(b) Effect of different temperature level on sclerotia formation by $S$. rolfsii (20 days after inoculation) 


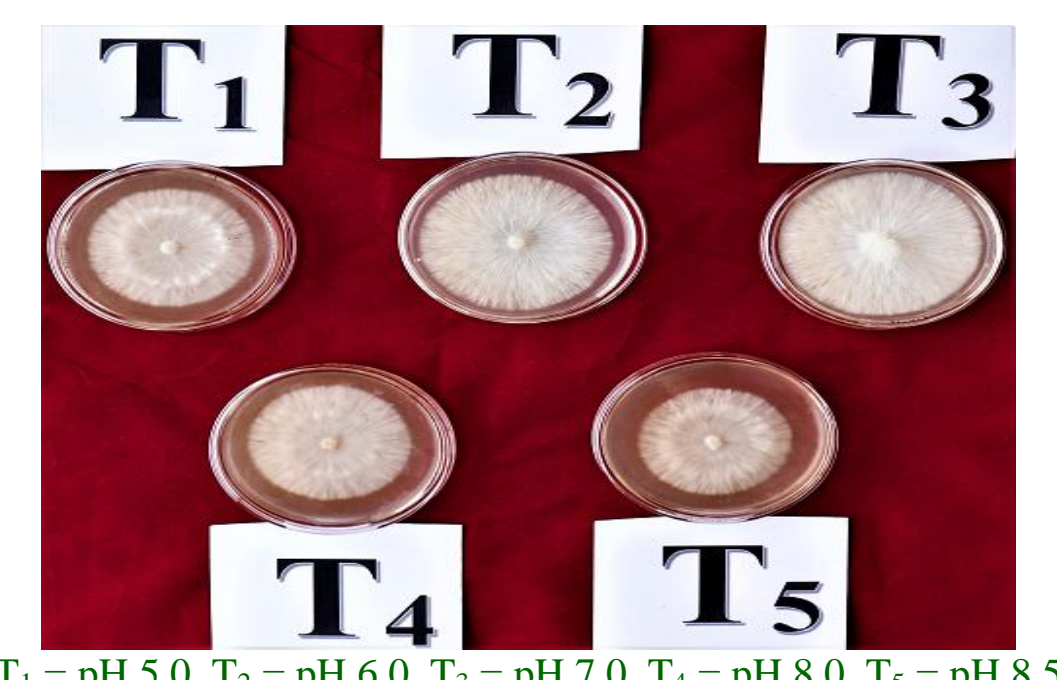

Plate.3(a) Effect of different $\mathrm{pH}$ level on mycelial growth of $S$. rolfsii(96 hrs. after inoculation)

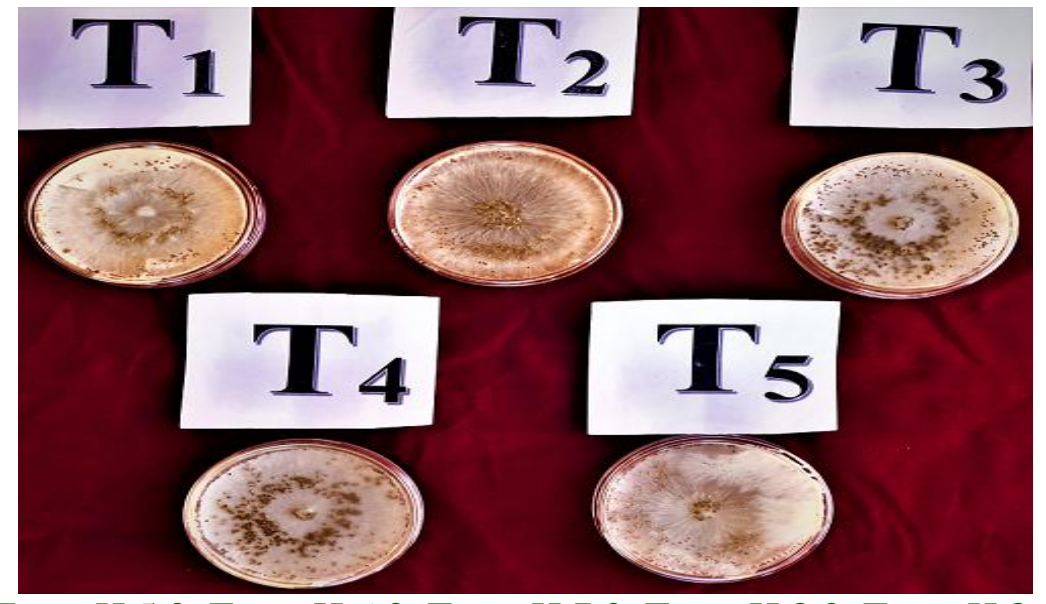

$\mathrm{T}_{1}=\mathrm{pH}$ 5.0, $\mathrm{T}_{2}=\mathrm{pH}$ 6.0, $\mathrm{T}_{3}=\mathrm{pH} 7.0, \mathrm{~T}_{4}=\mathrm{pH} 8.0, \mathrm{~T}_{5}=\mathrm{pH} 8.5$

Plate.3(b) Effect of different $\mathrm{pH}$ level on sclerotia formationbyS. Rolfsii (20 days after inoculation)

Sclerotium rolfsii was grown better under $\mathrm{pH}$ 6.0 which depicts the preference of slightly acidic condition by fungus. Next best radial growth was observed under $\mathrm{pH}$ 7.0. All other $\mathrm{pH}$ has shown declined growth rate and it was clear that $\mathrm{pH}$ beyond 9.0 is detrimental to pathogen.

This concludes that alkaline condition is not suitable for pathogen development. (Bana Sravani and Ram Chandra, 2020). Current experiment was conducted to unveil the suitable $\mathrm{pH}$, temperature and culture media required for the growth of pathogen. The findings and conclusions resulted from the study are here as follows. Among the eight tested culture media, Maximum colony diameter $(90.00 \mathrm{~mm})$ and sclerotia count (691.00) were recorded on oat meal agar (Himedia) at 96 hrs. and 20 days after inoculation respectively, followed by potato dextrose agar (natural) in radial mycelial growth $87.00 \mathrm{~mm}$ and potato dextrose agar (Hi-Media) in number of sclerotia count 665.00 per plates found to be best for providing better nutrients for pathogen growth and sclerotia formation. Sclerotium rolfsii was grown better under $\mathrm{pH}$ 7.0 which was followed by $\mathrm{pH}$ level 6.0, 
depicts the preference of slightly acidic condition by fungus. All other $\mathrm{pH}$ has shown declined growth and sclerotia formation by pathogen. Vigorous fungal radial growth and sclerotia production were observed under the temperature of $25^{\circ} \mathrm{C}$ followed by $30^{\circ} \mathrm{C}$. Temperatures above $35{ }^{\circ} \mathrm{C}$ and below $20^{\circ} \mathrm{C}$ have been recorded to be unfavourable for the growth of Sclerotium rolfsii.

\section{References}

Basamma, 2008. Integrated management of Sclerotium wilt of potato caused by Sclerotium rolfsii Sacc., M.Sc. (Agri.) Thesis, University of Agriculture Science,Dharwad. 1-113pp.

Dey, T. K., Ali, M. S., Goswami, B. K. and Siddique, A. M. 1992. Collar rot $(S$. rolfsii) of taro-a new disease in Bangladesh. Journal of root crops. 18:108-112.

Kumar, R., Mishra, P., Singh, G. and Prasad, C. S. 2008. Effect of media, temperature and $\mathrm{pH}$ on growth and sclerotial production of Sclerotium rolfsii. Annals of Plant Protection Sciences. 16(2):531-532.

Mathur, S. B. and Sinha, S. 1968. Disease Development in Guar (Cyamopsisps oraloides) and Gram (Cicer arietinum L.) attacked with Sclerotium rolfsii under different soil $\mathrm{pH}$ conditions. Indian Journal of
Phytopathology.62(4):319-322.

Muthukumar and Suthinraj, T. 2019. Effect of certain epidemiological factors on the growth and sclerotial production of Sclerotium rolfsii. Journal of Emerging Technologies and Innovative Research.6(2): 358-364.

Prasad, B. K., Thakur, S., Sinha, P. and Prasad A. 1986. Influence of nutritional factor, $\mathrm{pH}$ and temperature on growth of Sclerotium rolfsiiSacc. isolated from tomato fruits. Indian Journal of Mycology and Plant Pathology. 16(2): 209-212.

Punja, Z. K. 1985. The biology, ecology, and control of Sclerotium rolfsii. Annual Review of Phytopathology. 23: 97-127.

Sab, J. 2013. Studies on collar rot of Chickpea caused by Sclerotium rolfsii(Sacc.). M.Sc. (Agri) Thesis, University of Agriculture Science, Bangalore. 1-117 pp.

Sravani, B. and Chandra, R. 2020. Influence of media, $\mathrm{pH}$ and temperature on the growth of Sclerotium rolfsii (Sacc.) causing collar rot of chickpea. Journal of Pharmacognosy and Phytochemistry. 9(1): 174-178.

Zape, A. S., Gade, R. M. and Singh, R. 2013. Physiological studies on different media, $\mathrm{pH}$ and temperature on Sclerotium rolfsii Isolates of soyabean. Scholarly Journal of Agriculture Science. 2(6): 238-241.

\section{How to cite this article:}

Karan Singh, C. B. Meena, Chirag Gautam, B. K. Patidar and Koli. N. R. 2020. Nutritional and Epidemiological Requirements for Growth and Sclerotia Formation by Sclerotium rolfsii (Sacc.) Causing Collar Rot of Chickpea (Cicer areitinum L.). Int.J.Curr.Microbiol.App.Sci. 9(07): 645-656. doi: https://doi.org/10.20546/ijcmas.2020.907.074 